\title{
Kaji Banding Pertumbuhan dan Kadar Hara N,P dan K Tanaman Jagung (Zea mays L). pada Tiga Macam Pupuk Organik Berbeda Kualitas
}

\author{
M.Rizky Romadhoni ${ }^{1}$, Anis Sholihah ${ }^{2}$, Nurhidayati ${ }^{{ }^{*}}$ \\ ${ }^{1}$ Mahasiswa S1 Agroteknologi Fakultas Pertanian, Universitas Islam Malang \\ ${ }^{2}$ Dosen Agroteknologi, Fakultas Pertanian, Universitas Islam Malang \\ JI. MT. Haryono No. 193 Malang 65144, Jawa Timur, Indonesia \\ Korespondensi: nurhidayati@unisma.ac.id
}

\begin{abstract}
Abstrak
Jagung (Zea mays L.) merupakan komoditas tanaman pangan yang berperan penting dan strategis dalam pembangunan nasional. Penelitian ini bertujuan untuk mengetahui pertumbuhan dan kadar hara N,P,K akibat interaksi macam pupuk organik dengan dosis aplikasinya. Penelitian ini merupakan percobaan pot yang menggunakan Rancangan Acak Kelompok (RAK) Faktorial dengan Kontrol, faktor pertama adalah macam pupuk organik (vermikompos, pupuk kotoran sapi dan kompos seresah daun bambu) dan faktor kedua adalah dosis aplikasinya (5, 10, 15 dan 20 ton.ha $\left.{ }^{-1}\right)$. Dari dua faktor tersebut diperoleh 12 kombinasi perlakuan dan ditambah satu perlakuan kontrol. Tiap-tiap perlakuan diulang 3 kali. Ada dua variabel pengamatan yang dilakukan yaitu variabel tumbuh dan variabel kadar hara. Data yang diamati dianalisis dengan uji $F$ pada taraf $5 \%$. Jika terdapat pengaruh nyata maka dilanjut dengan uji BNJ 5\% dan uji Dunnet pada taraf $5 \%$. Dilakukan uji regresi untuk menentukan dosis optimum masing-masing pupuk organik. Hasil penelitian menunjukkan bahwa pertumbuhan tanaman terbaik adalah aplikasi vermikompos dengan dosis 15-20 ton.ha ${ }^{-1}$ dan pupuk kotoran sapi 10-20 ton.ha ${ }^{-1}$. Sedangkan perlakuan yang memberikan kadar hara tertinggi adalah aplikasi vermikompos dengan dosis 20 ton.ha ${ }^{-1}$.
\end{abstract}

Keywords: Jagung, Vermikompos, Pupuk Kotoran Sapi, Kompos Daun Bambu

\begin{abstract}
Corn (Zea mays L.) is a food crop commodity that plays an important and strategic role in national development. This study aims to describe the growth and nutrient content of $\mathrm{N}, \mathrm{P}$, $\mathrm{K}$ due to the interaction between the type of organic fertilizer and the dose of application. This research was a pot experiment which used Factorial Randomized Block Design (RAK) with Control. The first factor was the kinds of organic fertilizer (vermicompost, cow dung manure and bamboo leaf litter compost) and the second factor was the application dose $\left(5,10,15\right.$ and 20 ton.ha $\left.{ }^{-1}\right)$. Each treatment was repeated 3 times. There were two observed variables that were the growth and nutrient content variables. The observed data was analyzed by $\mathrm{F}$ test at $5 \%$ level. If there was a significant influence, it was continued with 5\% Tukey test and Dunnet test at 5\% level. The regression test was used to determine the optimum dose of each organic fertilizer. The research result indicated that the best plant growth was application of vermicompost with the dose of 15-20 ton.ha ${ }^{-1}$ and cow dung manure with the dose of 10-20 ton.ha ${ }^{-1}$. While the treatment that gave the highest nutrient content was vermicompost application with the dose of 20 ton.ha ${ }^{-1}$.
\end{abstract}

Keywords: Corn, Vermicompost, Cow Dung Manure, Bamboo Leaf Compost 


\section{Pendahuluan}

Jagung (Zea mays L.) merupakan komoditas tanaman pangan terbesar selain padi yang berperan penting di Indonesia. Pada tahun 2015 produksi jagung di Indonesia dengan luas panen 3.787.367 ha adalah 19.612.435 ton, sehingga produktivitasnya 5,18 ton.ha ${ }^{-1}$. Angka produktivitas ini masih tergolong rendah dibandingkan dengan potensi produksi jagung hibrida 9-10 ton.ha ${ }^{-1}$ (Badan Pusat Statistik, 2015). Rendahnya produktivitas jagung salah satunya disebabkan oleh kesuburan tanah yang rendah (Prihatman, 2000).

Kondisi kesuburan tanah di lahan pertanian semakin menurun karena rendahnya kandungan bahan organik dan penggunaan pupuk anorganik yang kurang tepat. Salah satu upaya yang dapat dilakukan adalah pemberian pupuk organik. Pupuk organik dapat berasal dari berbagai macam bahan organik antara lain pupuk kompos, kotoran hewan, pupuk hijau, vermikompos dll. Berbagai macam pupuk organik tersebut memiliki karakteristik yang berbeda baik dari segi komposisi kimia maupun karakter fisiknya.

Beberapa penelitian tentang aplikasi pupuk organik seperti vermikompos telah banyak dilakukan seperti pada tanaman tomat (Gutierrez-
Miceli et al., 2007), Paprika (Arancon et al., 2005), Strawberry (Arancon et al., 2004), kubis, brokoli dan sawi (Nurhidayati et al., 2016;2017a;2017b). Penelitian tentang pupuk kotoran sapi juga telah dilakukan seperti pada tanaman jagung (Tola et al., 2007). Namun demikian belum banyak dilakukan penelitian tentang aplikasi kompos daun bambu. Daun bambu memiliki $\mathrm{C} / \mathrm{N}$ rasio tinggi sebersar 35,82 38,27 (Baroroh, 2016), oleh karena itu perlu perlakuan khusus untuk dijadikan sebagai pupuk organik.

Penelitian ini bertujuan untuk membandingkan pengaruh beberapa macam pupuk organik yang memiliki karakteristik yang berbeda terhadap pertumbuhan dan kadar hara N,P dan K tanaman. Penelitian ini dapat memberikan manfaat kepada petani terkait dengan pengaruh beberapa alternatif sumber pupuk organik yang tersedia di lingkungan sekitar lahan pertanian, sehingga petani dapat memiliki pupuk organik yang dapat memberikan pengaruh yang signifikan terhadap pertumbuhan dan kadar hara tanaman jagung.

\section{Bahan Dan Metode}

Penelitian dilakukan di Desa Bumiayu, Kecamatan Kedungkandang, Kota Malang pada ketinggian 460 mdpl. 
Penelitian berlangsung pada 28 Oktober 2017 sampai 7 Januari 2018. Penelitian ini menggunakan Rancangan Acak Kelompok (RAK) Faktorial dengan Kontrol. Faktor pertama adalah macam pupuk organik (vermikompos, pupuk kotoran sapi dan kompos seresah daun bambu) dan faktor kedua adalah dosis aplikasinya $\left(5,10,15\right.$ dan 20 ton.ha $\left.{ }^{-1}\right)$. Ada dua variabel pengamatan yang dilakukan yaitu variabel tumbuh dan variabel kadar hara. Pengamatan dilakukan setiap 7 hari sekali untuk variabel tumbuh. Data hasil pengamatan dianalisis menggunakan Uji $\mathrm{F}$ pada taraf $5 \%$ jika terdapat pengaruh nyata maka dilanjut dengan uji BNJ 5\% dan uji Dunnet pada taraf 5\%. Untuk menentukan dosis optimum masingmasing pupuk organic dilakukan uji regresi.

Pembuatan vermikompos

dilakukan selama 1,5 bulan dengan menggunakan cacing Lumbricus rubellus. Pembuatan kompos daun bambu dilakukan selama 1 bulan, sedangkan untuk pupuk kotoran sapi dikeringkan terlebih dahulu kemudian dihaluskan. Media tanam yang digunakan yaitu tanah kering sebanyak 10 kg.polibag ${ }^{-1}$. Benih tanaman jagung varietas Bisi 18 ditanam secara langsung ke dalam polibag. Aplikasi pupuk organik (vermikompos, pupuk kotoran sapi, kompos daun bambu) dilakukan 7 hari sebelum tanam, sedangkan pupuk dasar $\mathrm{N}, \mathrm{P}, \mathrm{K}$ diaplikasikan pada umur 14 hst dengan dosis $1 / 2$ dosis anjuran. Pemeliharaan yang dilakukan meliputi penyiraman, penyiangan dan pemberantasan hama dan penyakit. Pengukuran pertumbuhan dilakukan dengan menggunakan penggaris atau meteran, sedangkan analisis kadar hara $\mathrm{N}, \mathrm{P}, \mathrm{K}$ dilakukan analisis di laboratorium dengan menggunakan metode destruksi basah pada sampel daun tanaman jagung. Daun tanaman jagung yang digunakan untuk sampel diambil pada saat seminggu sebelum tanaman memasuki fase generatif yaitu pada 57 hst.

\section{Hasil Dan Pembahasan}

Pengaruh aplikasi tiga macam pupuk organik dan dosis aplikasinya terhadap pertumbuhan tanaman

Hasil analisis ragam menunjukkan adanya pengaruh interaksi nyata antara macam pupuk organik dan dosis aplikasinya terhadap tinggi tanaman. Hasil uji BNJ 5\% (Tabel 1) menunjukkan bahwa perlakuan $\mathrm{P}_{1} \mathrm{D}_{4} \quad$ (aplikasi vermikompos dengan dosis 20 ton.ha ${ }^{-1}$ ) cenderung memiliki tinggi tanaman tertinggi dibandingkan perlakuan yang lain. Hasil uji Dunnet 5\% menunjukkan 
bahwa sebagian perlakuan tidak berbeda

nyata dengan kontrol kecuali perlakuan
1 dan pupuk kotoran sapi dengan dosis 15-20 ton. ha ${ }^{-1}$. vermikompos dengan dosis $15-20$ ton.ha

Tabel 1. Rata-rata tinggi tanaman $(\mathrm{cm})$ akibat interaksi perlakuan tiga macam pupuk organik serta dosis pupuk organik pada berbagai umur tanaman (hst).

\begin{tabular}{|c|c|c|c|c|c|c|}
\hline \multirow[t]{2}{*}{ Perlakuan } & \multicolumn{6}{|c|}{ Rata-Rata Tinggi Tanaman Jagung (cm) Pada Berbagai Umur (hst) } \\
\hline & 14 & 21 & 28 & 35 & 49 & 56 \\
\hline Kontrol & 19.78 & 25.72 & 44.40 & 60.60 & 81.90 & 85.85 \\
\hline$P_{1} D_{1}$ & 23.20 abcde & $29.39 a b^{*}$ & $50.93 a b c^{*}$ & $62.76 \mathrm{a}^{\mathrm{tn}}$ & $82.78 \mathrm{a}^{\mathrm{tn}}$ & $91.13 a b^{\text {tn }}$ \\
\hline$P_{1} D_{2}$ & 23.71 bcde $^{*}$ & $30.29 a b c{ }^{*}$ & $52.78 \mathrm{abcd}^{\pi}$ & $63.34 \mathrm{a}^{\mathrm{tn}}$ & $86.12 a b c^{\text {tn }}$ & $92.78 a b c^{t n}$ \\
\hline$P_{1} D_{3}$ & $24.74 \mathrm{cde}^{*}$ & $32.57 \mathrm{~cd}^{*}$ & 54.95 cde $^{*}$ & $70.58 a b^{*}$ & $91.37 \mathrm{bcd}^{*}$ & $107.81 \mathrm{~d}^{*}$ \\
\hline $\mathrm{P}_{1} \mathrm{D}_{4}$ & $26.51 e^{*}$ & $34.23 \mathrm{~d}^{*}$ & $57.27 e^{*}$ & $64.35 \mathrm{a}^{\mathrm{tn}}$ & $95.43 d^{*}$ & $104.87 \mathrm{~cd}^{*}$ \\
\hline $\mathrm{P}_{2} \mathrm{D}_{1}$ & $22.43 \mathrm{abcd}^{\mathrm{tn}}$ & $29.70 a b^{*}$ & $51.38 \mathrm{abcd}^{*}$ & $67.19 a b^{\text {tn }}$ & $89.20 \mathrm{abcd}^{\times}$ & $91.12 \mathrm{ab}^{\mathrm{tn}}$ \\
\hline $\mathrm{P}_{2} \mathrm{D}_{2}$ & 23.89 bcde & $32.48 \mathrm{~cd}^{*}$ & $52.72 \mathrm{abcd}^{*}$ & $69.27 a b^{*}$ & $90.86 \mathrm{bcd}^{*}$ & $93.00 a b c^{t n}$ \\
\hline $\mathrm{P}_{2} \mathrm{D}_{3}$ & $24.62 \mathrm{cde}^{*}$ & $33.43 \mathrm{~d}^{x}$ & 53.87 bcde & $68.11 a b^{x}$ & $93.07 \mathrm{~cd}^{\times}$ & $98.69 \mathrm{abcd}$ \\
\hline $\mathrm{P}_{2} \mathrm{D}_{4}$ & $25.47 \mathrm{de}^{\star}$ & $35.02 \mathrm{~d}^{x}$ & $55.62 \mathrm{de}^{\star}$ & $74.21 b^{x}$ & $93.12 \mathrm{~cd}^{\star}$ & $100.24 \mathrm{bcd}$ \\
\hline$P_{3} D_{1}$ & $21.79 a b c^{t n}$ & $27.94 a^{*}$ & $49.32 a^{*}$ & $64.47 \mathrm{a}^{\text {tn }}$ & $83.05 \mathrm{a}^{\mathrm{tn}}$ & $88.47 a^{\text {tn }}$ \\
\hline$P_{3} D_{2}$ & $20.68 a b^{\text {tn }}$ & $29.43 a b^{x}$ & $51.62 \mathrm{abcd}^{*}$ & $64.88 a^{\text {tn }}$ & $85.40 a b^{t n}$ & $89.52 a b^{\text {tn }}$ \\
\hline $\mathrm{P}_{3} \mathrm{D}_{3}$ & $20.06 a^{\text {tn }}$ & $30.63 b c^{*}$ & $53.04 \mathrm{abcde}^{x}$ & $63.32 a^{\text {tn }}$ & $88.63 \mathrm{abcd}^{\mathrm{tn}}$ & $92.17 \mathrm{ab}^{\mathrm{tn}}$ \\
\hline $\mathrm{P}_{3} \mathrm{D}_{4}$ & $20.00 a^{\text {tn }}$ & $28.93 a b^{*}$ & $50.17 \mathrm{ab}^{*}$ & $62.33 \mathrm{a}^{\text {tn }}$ & $82.28 a^{\operatorname{tn}}$ & $86.17 a^{\text {tn }}$ \\
\hline BNJ 5\% & 3.59 & 2.59 & 4.44 & 8.85 & 7.53 & 12.55 \\
\hline Dunnet 5\% & 2.94 & 2.12 & 3.64 & 7.24 & 6.16 & 10.26 \\
\hline
\end{tabular}

Hasil uji BNJ 5\% secara terpisah

(Tabel 2) menunjukkan bahwa pada pengamatan umur 42 hst perlakuan $\mathrm{P}_{2}$ (aplikasi pupuk kototan sapi) cenderung memiliki tinggi tanaman tertinggi, namun tidak berbeda nyata dengan perlakuan $\mathrm{P}_{1}$ (aplikasi vermikompos), dengan dosis aplikasi sebesar 20 ton.ha ${ }^{-1}$.

Hasil analisis ragam menunjukkan adanya pengaruh interaksi nyata antara macam pupuk organik dan dosis aplikasinya.
Tabel 2. Rata-rata tinggi tanaman (cm) akibat perlakuan tiga macam pupuk organik dan dosis pupuk organik pada umur 42 hst.

\begin{tabular}{cc}
\hline Perlakuan & $\begin{array}{c}\text { Rata-Rata Tinggi } \\
\text { Tanaman }(\mathrm{cm})\end{array}$ \\
\hline $\mathrm{P}_{1}$ & $967.53 \mathrm{~b}$ \\
$\mathrm{P}_{2}$ & $968.10 \mathrm{~b}$ \\
$\mathrm{P}_{3}$ & $926.23 \mathrm{a}$ \\
\hline BNJ 5\% & 4.28 \\
\hline $\mathrm{D}_{1}$ & $934.11 \mathrm{a}$ \\
$\mathrm{D}_{2}$ & $971.24 \mathrm{~b}$ \\
$\mathrm{D}_{3}$ & $1029.19 \mathrm{c}$ \\
$\mathrm{D}_{4}$ & $1111.21 \mathrm{~d}$ \\
\hline
\end{tabular}

BNJ 5\% 4.95

Keterangan : Angka yang didampingi huruf yang sama pada kolom yang sama menunjukkan tidakberbeda nyata pada uji BNJ 5\%, TN : Tidak Nyata 
Hasil uji BNJ 5\% (Tabel 3) menunjukkan bahwa perlakuan $\mathrm{P}_{2} \mathrm{D}_{4}$ (aplikasi pupuk kotoran sapi dengan dosis 20 ton.ha ${ }^{-1}$ ) cenderung memiliki jumlah daun terbanyak. Hasil uji Dunnet $5 \%$ menunjukkan bahwa pada umur pengamatan 21 hst sebagian besar perlakuan menunjukkan tidak berbeda nyata dengan kontrol kecuali pada perlakuan $\mathrm{P}_{2} \mathrm{D}_{4}$ (aplikasi pupuk kotoran sapi dengan dosis 20 ton.ha-1).
Pada umur pengamatan 56 hst sebagian perlakuan berbeda nyata dengan kontrol kecuali pada perlakuan vermikompos dengan dosis 5-10 ton.ha ${ }^{-1}$ dan pupuk kompos seresah daun bambu dengan dosis 15-20 ton.ha-1.

Hasil uji BNJ 5\% (Tabel 4) menunjukkan bahwa perlakuan vermikompos cenderung memberikan jumlah daun terbanyak. Dosis pupuk organik yang memberikan jumlah daun terbanyak adalah 15 ton.ha ${ }^{-1}$.

Tabel 3. Rata-rata jumlah daun (helai) akibat interaksi perlakuan tiga macam pupuk serta dosis pupuk organik pada berbagai umur tanaman (hst).

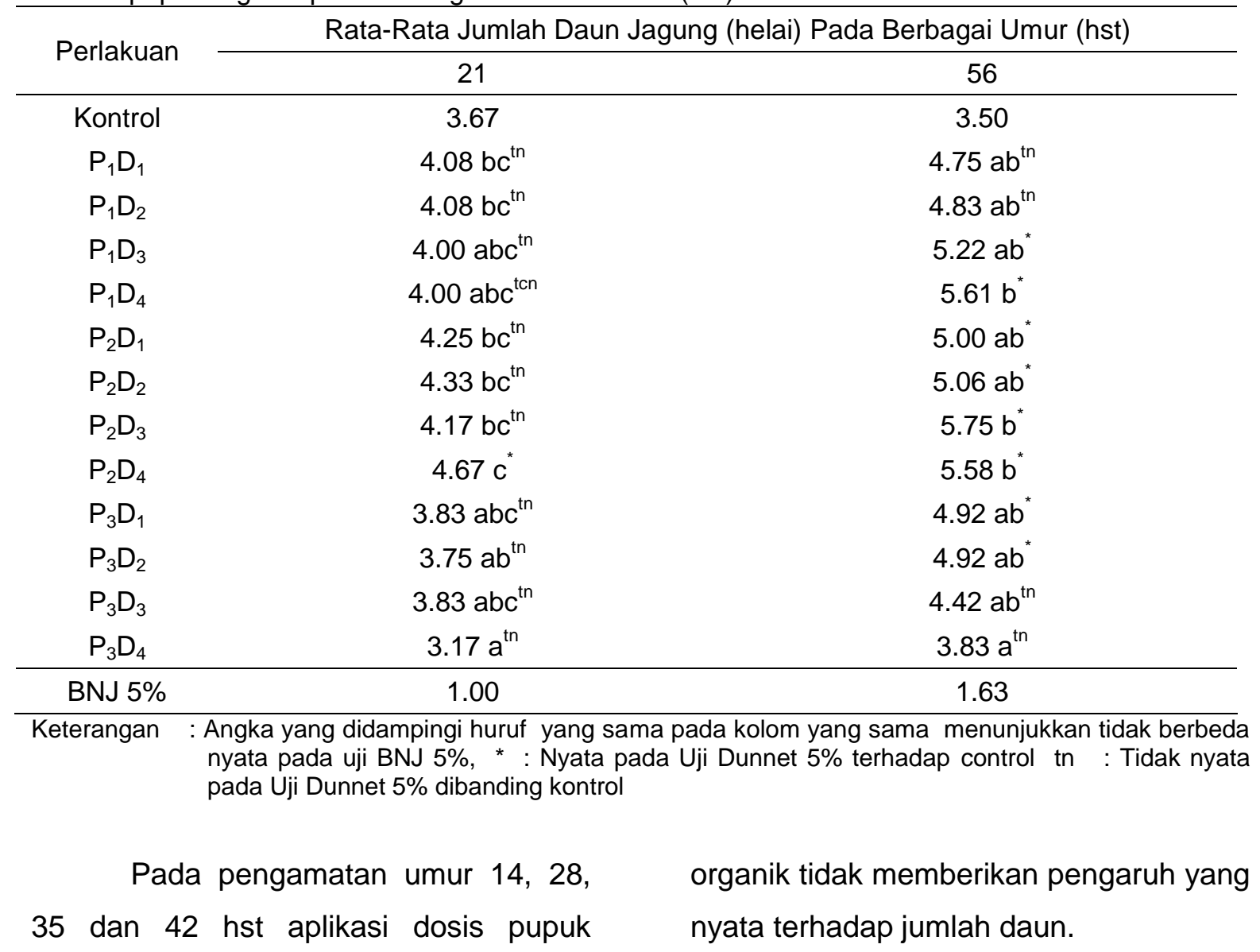


Hasil analisis ragam menunjukkan adanya pengaruh interaksi nyata antara macam pupuk organik dan dosis aplikasinya terhadap luas daun (Tabel 5).

Tabel 4. Rata-rata jumlah daun (helai) akibat perlakuan tiga macam pupuk organik dan dosis pupuk organik.

\begin{tabular}{cccccc}
\hline \multirow{2}{*}{ Perlakuan } & \multicolumn{5}{c}{ Rata-Rata Jumlah Daun Jagung (helai) Pada Berbagai Umur (hst) } \\
\cline { 2 - 6 } & 14 & 28 & 35 & 42 & 49 \\
\hline $\mathrm{P}_{1}$ & $9,00 \mathrm{~b}$ & $13.73 \mathrm{~b}$ & 8.54 & 6.00 & $10.75 \mathrm{~b}$ \\
$\mathrm{P}_{2}$ & $9.13 \mathrm{~b}$ & $12.79 \mathrm{a}$ & 8.17 & 6.81 & $10.58 \mathrm{~b}$ \\
$\mathrm{P}_{3}$ & $7.54 \mathrm{a}$ & $12.69 \mathrm{a}$ & 7.85 & 6.06 & $9.13 \mathrm{a}$ \\
\hline BNJ 5\% & 0.32 & 0.34 & $\mathrm{TN}$ & $\mathrm{TN}$ & 0.67 \\
\hline $\mathrm{D}_{1}$ & 8.67 & 12.86 & 7.92 & 6.25 & $9.67 \mathrm{ab}$ \\
$\mathrm{D}_{2}$ & 8.58 & 12.94 & 7.92 & 6.33 & $9.44 \mathrm{a}$ \\
$\mathrm{D}_{3}$ & 8.61 & 13.36 & 8.42 & 6.50 & $11.19 \mathrm{c}$ \\
$\mathrm{D}_{4}$ & 8.36 & 13.11 & 8.50 & 6.08 & $10.31 \mathrm{~b}$ \\
\hline BNJ 5\% & TN & TN & TN & TN & 0.77 \\
\hline Keterangan & : Angka yang didampingi huruf & yang sama pada kolom yang sama & menunjukkan tidak \\
& berbeda nyata pada uji BNJ 5\%, TN : Tidak Nyata. & &
\end{tabular}

Tabel 5. Rata-rata luas daun $\left(\mathrm{cm}^{2}\right)$ akibat interaksi perlakuan tiga macam pupuk organik serta dosis pupuk organik pada berbagai umur tanaman (hst).

\begin{tabular}{|c|c|c|c|c|c|}
\hline \multirow{2}{*}{ Perlakuan } & \multicolumn{5}{|c|}{ Rata-Rata Luas Daun Tanaman Jagung $\left(\mathrm{cm}^{2}\right)$ Pada Berbagai Umur (hst) } \\
\hline & 14 & 21 & 28 & 49 & 56 \\
\hline Kontrol & 30.11 & 51.82 & 99.76 & 389.24 & 404.47 \\
\hline$P_{1} D_{1}$ & $38.17 \mathrm{abcd}^{\star}$ & $69.86 \mathrm{abcd}^{\star}$ & $167.30 \mathrm{bc}^{\star}$ & $478.79 \mathrm{bc}^{\star}$ & $432.74 a b^{t n}$ \\
\hline$P_{1} D_{2}$ & $40.16 \mathrm{abcd}^{*}$ & 77.98 abcde & $176.49 \mathrm{~cd}^{*}$ & $515.09 \mathrm{~cd}^{*}$ & $450.03 a b c^{\text {tn }}$ \\
\hline$P_{1} D_{3}$ & $43.83 \mathrm{bcd}^{*}$ & 82.72 bcde $^{*}$ & $192.31 \mathrm{cde}^{*}$ & $549.36 \mathrm{~d}^{*}$ & $500.86 \mathrm{~cd}^{*}$ \\
\hline$P_{1} D_{4}$ & $45.35 \mathrm{~d}^{*}$ & $87.01 \mathrm{cde}^{*}$ & $222.93 \mathrm{e}^{*}$ & $512.52 \mathrm{~cd}^{*}$ & $521.96 \mathrm{~d}^{*}$ \\
\hline$P_{2} D_{1}$ & $38.00 \mathrm{abcd}^{*}$ & $67.11 \mathrm{abcd}^{\mathrm{tn}}$ & $172.13 \mathrm{bc}^{*}$ & $448.17 \mathrm{ab}^{*}$ & $441.64 \mathrm{abc}^{\mathrm{tn}}$ \\
\hline$P_{2} D_{2}$ & $40.56 \mathrm{abcd}^{*}$ & 77.19 abcde & 202.49 cde $^{*}$ & $517.96 \mathrm{~cd}^{*}$ & $494.84 \mathrm{bcd}^{*}$ \\
\hline$P_{2} D_{3}$ & $43.20 \mathrm{bcd}^{*}$ & $88.13 \mathrm{de}^{*}$ & $221.39 \mathrm{de}^{*}$ & $534.16 \mathrm{~d}^{*}$ & $518.68 \mathrm{~d}^{*}$ \\
\hline $\mathrm{P}_{2} \mathrm{D}_{4}$ & $44.23 \mathrm{~cd}^{*}$ & $97.99 e^{*}$ & $224.66 \mathrm{e}^{*}$ & $566.03 \mathrm{~d}^{*}$ & $532.76 \mathrm{~d}^{*}$ \\
\hline$P_{3} D_{1}$ & $35.74 a b^{\text {tn }}$ & $63.05 \mathrm{abc}^{\mathrm{tn}}$ & $108.64 \mathrm{a}^{\mathrm{tn}}$ & $400.03 \mathrm{a}^{\pi}$ & $436.99 a b c^{t n}$ \\
\hline $\mathrm{P}_{3} \mathrm{D}_{2}$ & $35.95 a b c^{\text {tn }}$ & $58.18 \mathrm{a}^{\mathrm{tn}}$ & $131.13 a b^{t n}$ & $440.48 a b^{*}$ & $439.83 a b c^{t n}$ \\
\hline $\mathrm{P}_{3} \mathrm{D}_{3}$ & $33.76 \mathrm{a}^{\mathrm{tn}}$ & $63.45 a b c^{\text {tn }}$ & $115.18 a^{\text {tn }}$ & $469.56 b^{\star}$ & $444.42 a b c^{\text {tn }}$ \\
\hline$P_{3} D_{4}$ & $32.61 \mathrm{a}^{\text {tn }}$ & $62.06 \mathrm{ab}^{\text {tn }}$ & $130.54 a \mathrm{ab}^{\mathrm{tn}}$ & $458.82 b^{\pi}$ & $425.25 \mathrm{a}^{\mathrm{tn}}$ \\
\hline BNJ 5\% & 8.45 & 21.89 & 45.10 & 54.98 & 66.30 \\
\hline Dunnet 5\% & 6.91 & 17.90 & 36.89 & 44.97 & 54.23 \\
\hline rangan & $: \mathrm{Ti}$ & Uii L & alla & & $\begin{array}{l}\text { unjukka } \\
\text { control }\end{array}$ \\
\hline
\end{tabular}

Hasil uji BNJ 5\% (Tabel 5) menunjukkan bahwa perlakuan $\mathrm{P}_{2} \mathrm{D}_{4}$ (aplikasi pupuk kotoran sapi dengan dosis 20 ton.ha ${ }^{-1}$ ) cenderung memiliki luas daun tertinggi tetapi tidak berbeda nyata dengan perlakuan vermikompos dengan dosis 15-20 ton.ha ${ }^{-1}$ dan pupuk kotoran sapi dengan dosis 10-15 ton.ha' ${ }^{-1}$. Hasil uji Dunnet 5\% menunjukkan sebagian perlakuan tidak berbeda nyata dengan kontrol kecuali perlakuan vermikompos dengan dosis $15-20$ ton.ha 
${ }^{1}$ dan pupuk kotoran sapi dengan dosis 10-20 ton.ha ${ }^{-1}$.

Hasil uji BNJ 5\% secara terpisah (Tabel 6) menunjukkan bahwa perlakuan $P_{1}$ (aplikasi vermikompos) cenderung memberikan luas daun tertinggi tetapi tidak berbeda nyata dengan perlakuan $\mathrm{P}_{2}$ (aplikasi kotoran sapi). Sedangkan dosis aplikasinya yang memberikan luas daun terbesar adalah 15-20 ton.ha ${ }^{-1}$.

Tabel 6. Rata-rata luas daun $\left(\mathrm{cm}^{2}\right)$ akibat perlakuan tiga macam pupuk organik dan dosis pupuk organik pada umur 35 dan 42 hst.

\begin{tabular}{ccc}
\hline \multirow{2}{*}{ Perlakuan } & \multicolumn{2}{c}{ Rata-Rata Luas Daun $\left(\mathrm{cm}^{2}\right)$} \\
\cline { 2 - 3 } & $35 \mathrm{hst}$ & $42 \mathrm{hst}$ \\
\hline $\mathrm{P}_{1}$ & $1124.17 \mathrm{c}$ & $1213.23 \mathrm{~b}$ \\
$\mathrm{P}_{2}$ & $1070.79 \mathrm{~b}$ & $1216.7 \mathrm{~b}$ \\
$\mathrm{P}_{3}$ & $839.36 \mathrm{a}$ & $1040.74 \mathrm{a}$ \\
\hline BNJ 5\% & 41.52 & 37.35 \\
\hline $\mathrm{D}_{1}$ & $934.11 \mathrm{a}$ & $1044.39 \mathrm{a}$ \\
$\mathrm{D}_{2}$ & $971.24 \mathrm{a}$ & $1132.46 \mathrm{~b}$ \\
$\mathrm{D}_{3}$ & $1029.19 \mathrm{~b}$ & $1215.08 \mathrm{c}$ \\
$\mathrm{D}_{4}$ & $1111.21 \mathrm{C}$ & $1235.62 \mathrm{c}$ \\
\hline BNJ 5\% & 47.94 & 43.12 \\
\hline Keterangan & $:$ Angka yang didampingi huruf yang sama pada kolom yang sama menunjukkan tidak \\
\hline & berbeda nyata pada uji BNJ 5\%, TN : Tidak Nyata
\end{tabular}

Berdasarkan hasil analisis statistik variabel tumbuh menunjukkan bahwa perlakuan yang memberikan pertumbuhan tinggi tanaman, jumlah daun dan luas daun terbaik secara umum pada perlakuan aplikasi vermikompos dengan dosis 15-20 ton.ha ${ }^{-1}$ dan pupuk kandang dengan dosis 10-20 ton.ha ${ }^{-1}$. Hal ini menunjukkan bahwa vermikompos dan pupuk kotoran sapi dapat membantu pertumbuhan tanaman jagung.

Hasil penelitian ini juga memperlihatkan bahwa aplikasi pupuk seresah daun bambu memiliki pertumbuhan dan serapan hara paling rendah dibandingkan dengan pupuk vermikompos dan kotoran sapi (kecuali kontrol) karena pupuk kompos serasah daun bambu yang digunakan dalam penelitian ini memiliki $\mathrm{C} / \mathrm{N}$ rasio tinggi. Hal ini menunjukkan bahwa pupuk organik tersebut belum matang dan perlu pengomposan yang lebih lama. Bila diaplikasikan pada kondisi ini akan mengakibatkan terjadinya defisiensi hara akibat proses immobilisasi (Nurhidayati, 2017).

Perbedaan pertumbuhan yang terjadi pada penelitian ini disebabkan 
oleh perbedaan kualitas dari pupuk organik yang digunakan. Menurut Nurhidayati (2017), kualitas $\mathrm{C} / \mathrm{N}$ rasio yang rendah dan kandungan $\mathrm{N}$ yang tinggi menunjukkan kualitas bahan organik yang tinggi, karena $\mathrm{C} / \mathrm{N}$ rasio dan kandungan $\mathrm{N}$ yang rendah lebih cepat terdekomposisi dari pada yang tinggi. Lignin dan fenol yang tinggi akan menghambat proses dekomposisi pupuk organik sehingga kandungan lignin dan fenol yang rendah menunjukkan kualitas bahan organik yang tinggi (Min et.al., 2015; Rahman et.al., 2013).

Tabel 7. Rata - rata kandungan unsur hara (\%) akibat interaksi perlakuan tiga macam pupuk organik serta dosis pupuk organik.

\begin{tabular}{|c|c|c|c|}
\hline \multirow[t]{2}{*}{ Perlakuan } & \multicolumn{3}{|c|}{ Kandungan Unsur Hara (\%) } \\
\hline & $\mathrm{N}$ & $P$ & $\mathrm{~K}$ \\
\hline Kontrol & 0.878 & 0.106 & 0.534 \\
\hline$P_{1} D_{1}$ & $1.226 b^{*}$ & $0.133 \mathrm{bc}$ & $0.673 \mathrm{bcd}^{x}$ \\
\hline$P_{1} D_{2}$ & $1.608 \mathrm{ef}^{\circ}$ & 0.144 ef & 0.713 ef $^{x}$ \\
\hline$P_{1} D_{3}$ & $1.779 \mathrm{~h}^{*}$ & $0.155 \mathrm{~h}^{*}$ & $0.752 \mathrm{~g}^{*}$ \\
\hline$P_{1} D_{4}$ & $1.701 \mathrm{gh}^{*}$ & $0.167 j^{*}$ & $0.800 \mathrm{~h}^{*}$ \\
\hline $\mathrm{P}_{2} \mathrm{D}_{1}$ & $1.173 a b^{*}$ & $0.127 a b$ & $0.649 b^{*}$ \\
\hline$P_{2} D_{2}$ & $1.461 \mathrm{~d}^{*}$ & $0.140 \mathrm{de}$ & $0.696 \mathrm{de}^{*}$ \\
\hline $\mathrm{P}_{2} \mathrm{D}_{3}$ & $1.652 \mathrm{fg}^{*}$ & $0.152 \mathrm{gh}$ & $0.739 \mathrm{fg}^{*}$ \\
\hline $\mathrm{P}_{2} \mathrm{D}_{4}$ & $1.703 \mathrm{gh}^{\star}$ & $0.161 i^{\pi}$ & $0.782 \mathrm{~h}^{\times}$ \\
\hline $\mathrm{P}_{3} \mathrm{D}_{1}$ & $1.098 \mathrm{a}^{*}$ & $0.122 \mathrm{a}^{*}$ & $0.621 \mathrm{a}^{*}$ \\
\hline$P_{3} D_{2}$ & $1.368 c^{*}$ & $0.131 b^{*}$ & $0.660 \mathrm{bc}{ }^{*}$ \\
\hline$P_{3} D_{3}$ & $1.516 \mathrm{de}^{*}$ & $0.137 \mathrm{~cd}$ & $0.685 \mathrm{~cd}^{*}$ \\
\hline$P_{3} D_{4}$ & $1.681 \mathrm{fg}^{*}$ & $0.146 \mathrm{fg}^{*}$ & 0.718 ef $^{*}$ \\
\hline BNJ 5\% & 0.092 & 0.005 & 0.026 \\
\hline Dunnet 5\% & 0.075 & 0.004 & 0.021 \\
\hline
\end{tabular}

Keterangan : Angka yang didampingi huruf yang sama pada kolom yang sama menunjukkan tidak berbeda nyata pada uji BNJ 5\%, * : Nyata pada Uji Dunnet $5 \%$ terhadap kontrol ; tn : Tidak nyata pada Uji Dunnet $5 \%$ dibanding control

Pengaruh aplikasi tiga macam pupuk organik dan dosis aplikasinya terhadap kadar hara $N, P$ dan $K$ tanaman jagung

Hasil analisis ragam menunjukkan adanya pengaruh interaksi nyata pada perlakuan macam pupuk organik dan dosis pupuk organik terhadap kadar N, P dan K. Hasil uji BNJ 5\% dan Dunnet 5\% pada rata-rata serapan hara disajikan pada Tabel 7.

$$
\text { Hasil uji BNJ 5\% (Tabel 7) }
$$
menunjukkan bahwa kadar hara N, P dan $\mathrm{K}$ tertinggi terdapat pada perlakuan $\mathrm{P}_{1} \mathrm{D}_{4}$ (aplikasi vermikompos dengan dosis 20 ton. ha $\left.{ }^{-1}\right)$. Hasil uji Dunnet 5\% menunjukkan bahwa kadar hara N, P dan 
K semua perlakuan berbeda nyata dengan kontrol.

Berdasarkan Gambar 1 tersebut hubungan antara dosis pupuk organik dan kadar hara $\mathrm{N}$ tanaman untuk vermikompos ada kecenderungan mengikuti pola kuadratik artinya semakin tinggi dosis pupuk organik hingga tingkat tertentu kadar $\mathrm{N}$ semakin tinggi, melampaui titik tersebut kadar $\mathrm{N}$ tanaman menurun. Berdasarkan persamaan regresi $P_{1}=-0,0046 x^{2}+$ $0,1468 x+0,605$ dengan nilai determinasi (tingkat pengaruh dosis pupuk terhadap kadar hara N) sebesar 95,51\% diperoleh dosis optimum sebesar 15,96 ton.ha ${ }^{-1}$ dengan kadar $\mathrm{N}$ maksimum sebesar $1,78 \%$. Hubungan dosis pupuk organik dan kadar hara $\mathrm{N}$ tanaman pada pupuk kotoran sapi dan kompos daun bambu mengikuti pola linier artinya semakin tinggi dosis maka semakin tinggi pula kadar N. sehingga dosis yang diaplikasikan perlu ditambah untuk menemukan dosis optimumnya.

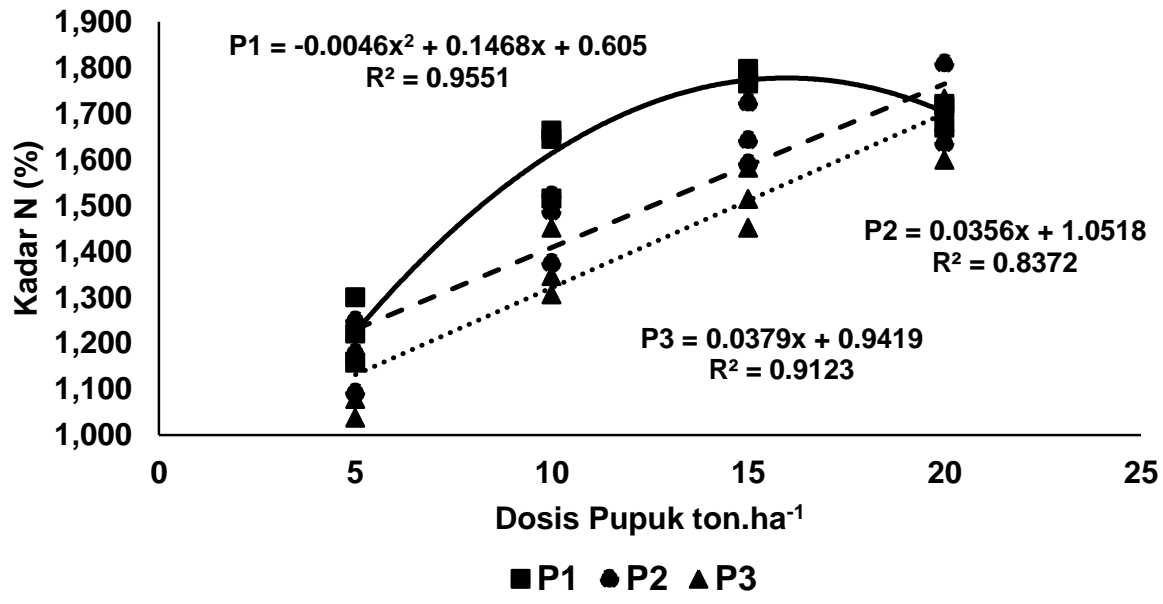

Gambar 1. Grafik hubungan dosis pupuk dengan kadar hara N pada tiga macam vermikompos

Berdasarkan Gambar (2 dan 3) hubungan antara dosis pupuk organik dan kadar hara $\mathrm{P}$ dan $\mathrm{K}$ tanaman untuk vermikompos, pupuk kotoran sapi dan kompos daun bambu mengikuti pola linier artinya semakin tinggi dosis maka semakin tinggi pula kadar $\mathrm{P}$ dan $\mathrm{K}$. sehingga dosis yang diaplikasikan perlu ditambah untuk menemukan dosis optimumnya.

Hasil analisis statistik memperlihatkan bahwa perlakuan aplikasi vermikompos dengan dosis 20 ton.ha ${ }^{-1}$ memiliki kadar hara yang paling tinggi dibandingkan dengan perlakuan yang lain. 


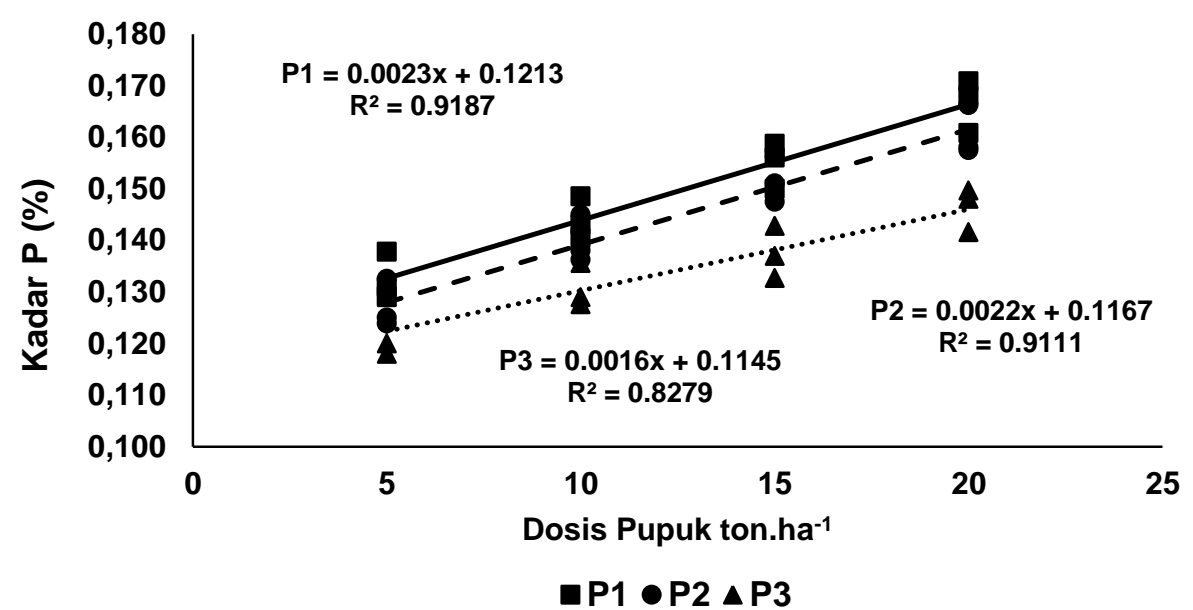

Gambar 2. Grafik hubungan dosis pupuk dengan kadar hara P pada tiga macam vermikompos

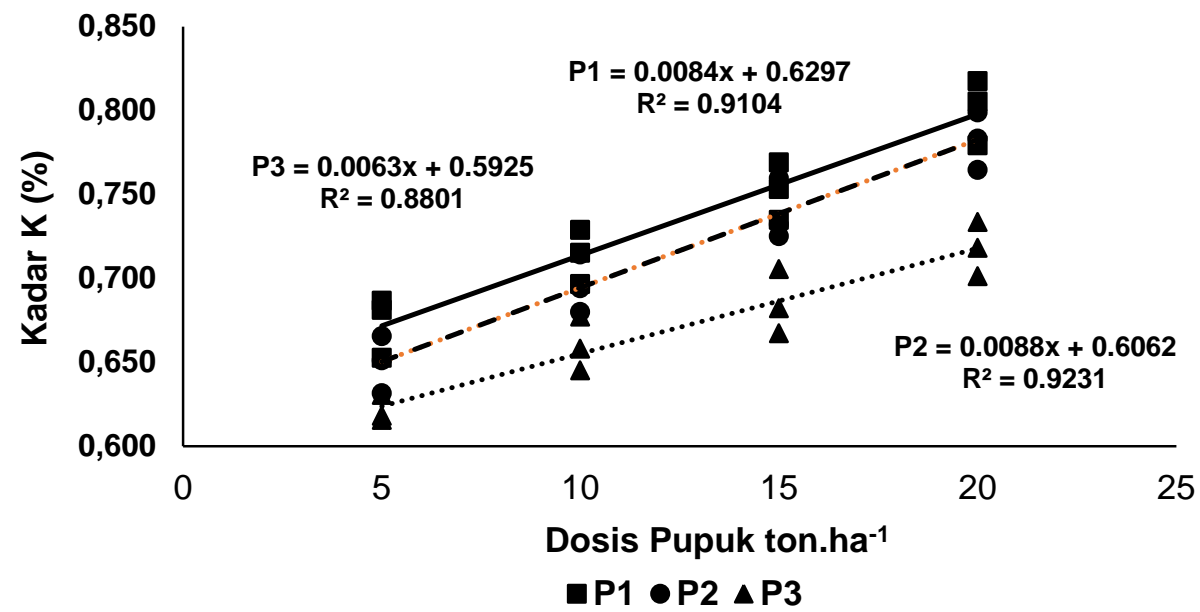

Gambar 3. Grafik hubungan dosis pupuk dengan kadar hara K pada tiga macam vermikompos

Hal ini menunjukkan bahwa pupuk vermikompos memiliki kandungan unsur hara yang lebih tinggi dibandingkan pupuk kotoran sapi dan pupuk seresah daun bambu dengan dosis yang sama. Hasil penelitian ini memperlihatkan bahwa kadar hara $\mathrm{N}$ pada perlakuan vermikompos dengan dosis 5 ton.ha $^{-1}$, pupuk kotoran sapi dengan dosis 5 ton.ha ${ }^{-1}$ dan kompos seresah daun bambu dengan dosis 5-10 ton. ha $^{-1}$ berada dibawah batas kritis. Hal ini menunjukkan terjadinya defisiensi hara $\mathrm{N}$ tanaman jagung pada perlakuan tersebut. Penelitian ini juga menunjukkan bahwa kadar hara $P$ selain pada perlakuan vermikompos dengan dosis 20 ton.ha-1 dan pupuk kotoran sapi dengan dosis 20 ton. ha $^{-1}$ berada dibawah batas kritis. 
Gejala dari kekurangan unsur N adalah tanaman tumbuh lambat dan kerdil, daun menyempit dan pendek. Apabila kekurangan unsur $\mathrm{N}$ tersebut dimulai pada awal pertumbuhan, maka seluruh permukaan daun berwarna hijau akan kekuningan (McCauley and Jones, 2011). Kekurangan unsur $P$ pada tanaman jagung dapat menghambat pertumbuhan tanaman, yaitu tanaman pendek, pada awal pertumbuhan pinggir daun berwarna ungu kemerahan, mulai dari ujung hingga ke pangkal daun (Uchida, 2000). Tanaman jagung yang kekurangan hara $\mathrm{K}$ akan menunjukkan gejala berupa daun berbintik kuning cokelat, atau terjadi khlorosis. Pada daun bagian bawah, daun berwarna kuning membentuk huruf $\mathrm{V}$ terbalik. Bagian pinggir daun biasanya berwarna cokelat seperti terbakar, tapi tulang daun tetap hijau (Uchida, 2000).

\section{Kesimpulan dan Saran}

Berdasarkan hasil penelitian dapat disimpulkan bahwa Pertumbuhan dan kadar hara N, P, K tanaman jagung yang menggunakan aplikasi vermikompos memperlihatkan hasil yang lebih tinggi dibandingkan dengan perlakuan yang lain tetapi cenderung tidak berbeda nyata dengan perlakuan pupuk kotoran sapi, sedangkan untuk pertumbuhan tanaman jagung terbaik terdapat pada perlakuan vermikompos dengan dosis $15-20$ ton.ha ${ }^{-1}$ dan pupuk kotoran sapi dengan dosis 10-20 ton. ha $^{-1}$ - Dosis optimum untuk kadar hara N pada vermikompos sebesar 15,96 ton. ha $^{-1}$ dengan kadar $\mathrm{N}$ maksimum $1,78 \%$. Sedangkan untuk dosis kadar $N$ pada pupuk kotoran sapi dan kompos seresah daun bambu tidak dapat ditentukan dosis optimumnya karena mengikuti pola linier. Hasil penelitian menunjukkan pertumbuhan yang kurang maksimal maka disarankan penelitian lanjutan dengan ditambah pupuk anorganik sesuai anjuran mengingat kompos yang dihasilkan terutama daun bambu masih memiliki $\mathrm{C} / \mathrm{N}$ rasio yang tinggi.

\section{Daftar Pustaka}

Arancon, N.Q., C.A. Edwards, P. Bierman, C. Welch, and J.D. Metzger. 2004. Influences of vermicomposts on field strawberries: 1. Effects on growth and yields. Bioresource Technology. 93: $145-153$.

Arancon, N.Q., C.A. Edwards, P. Bierman, J.D. Metzger, and C. Lucht. 2005. Effect of vermicompost produced from cattle manure, food waste and paper waste on the growth and yield of peppers in the field. Pedobiologia, 49: 297-306.

Badan Pusat Statistik. 2015. Laporan Tahunan Direktorat Jendral Tanaman Pangan. Jakarta. 97 hal.

Baroroh, A. 2016. Analisis Kandungan Unsur Hara Makro pada Pupuk 
Kompos dari Seresah Daun Bambu dan Limbah Padat Pabrik Gula (Blotong). Universitas Negeri Surakarta.

Gutiérrez-Miceli, F.A., J.S. Borraz, J.A.M. Molina, C.C. Nafate, M. Abud-Archila, M.A.O. Llaven, R. Rincó n-Rosales, and L. Dendooven. 2007. Vermicompost as a soil supplement to improve growth, yield and fruit quality of tomato

(Lycopersicum esculentum). Bioresource Technology. 98: 2781-2786

McCauley, A. and C. Jones. 2011. Plant Nutrient functions and Deficiency and Toxicity Symptoms. In MSU Extension Service Continuing Education Series. Montana State university. Bozeman.

Min, K., C. Freeman, H. Kang, and S. Choi. 2015. The Regulation by Phenolic Compounds of Soil Organic matter Dynamics under a Changing Environment. BioMed Research International. 2015 :ID 825098 11 pages. http://dx.doi.org/10.1155/2015/8250 98

Nurhidayati, M. Machfudz, dan I. Murwani. 2017a. Pertumbuhan, Hasil dan Kualitas Tanaman Brokoli (Brassica oleraceae L.) Sebagai Respon Terhadap Aplikasi Tiga Macam Vermikompos dengan Sistem Penanaman Secara Organik. Prosiding. Seminar Nasional. Fakultas Pertanian Universitas Nasional Jakarta, 8 Februari 2017. ISBN: 978-60261781-0-7

Nurhidayati, M. Machfudz, and I. Murwani. 2017b. Combined Effect of Vermicompost and earthworm Pontoscolex corethrurus
Inoculation on The Yield and Quality of Broccoli (Brassica oleraceae L.) Using Organic Growing Media. Journal of Basic and Applied Research International. 22 (4): 148-156

Nurhidayati, U. Ali, and I. Murwani. 2016. Yield and Quality of Cabbage (Brassica oleraceae L. var. capitata) Under Organic Growing Media Using Vermicompost and earthworm Pontoscolex corethrurus Inoculation. Agriculture and Agricultural Science Procedia II (2016): 5-13

Nurhidayati. 2017. Kesuburan dan Kesehatan Tanah : Suatu Pengantar Penilaian Kualitas Tanah Menuju Pertanian Berkelanjutan. Intimedia. Malang. 293 hal.

Prihatman. 2000. Jagung (Zea may L.). TTG Budidaya Pertanian, Kantor Deputi Menegristek Bidang Pendayagunaan dan Pemasyarakatan IImu Pengetahuan dan Teknologi. Jakarta. 17 hal

Tola, F. Hamzah, Dahlan, dan Kaharuddin. 2007. Pengaruh penggunaan dosis pupuk bokashi kotoran sapi terhadap pertumbuhan dan produksi tanaman jagung. Jurnal Agrosistem. 3 (1): 1-8.

Uchida, R. 2000. Essential Nutrient for Plant Growth Nutrient Functions and Deficiency Symptoms. In J.A. Silva and R. Uchida, eds. Plant Nutrient Management in Hawaii's Soil, Approachs for Tropical and Subtropical Agriculture. College of Tropical Agriculture and Human Resources, University of Ha waii at Manoa. 